\title{
The Evolvement of Autonomous Learning Through Social Constructivist Movement
}

\author{
Samira Hammoodi ${ }^{I}$ \\ Akbar Rahimi Alishah ${ }^{2}$
}

\begin{abstract}
One of the purpose of education is to develop students' autonomous learning ability. Education needs to constantly develop to maintain student achievement is effectively performed. Teachers should be creative in order to manage the educational process effectively. Teachers should find ways to increase student engagement, assessment, and motivation. Instructors can help students to trust themselves both in education and social lives. Constructivist movement cultivates assertion on the students' active learning, such as context and society to foster instruction or scaffolding and enhance student motivation, autonomy, comprehension, collaboration, and student performance. Actually, autonomous learning is a popular aim. It is one of the most important principles for practical, pedagogical, and philosophical purposes. Instructors use scaffolding to enhance students towards independence. This paper aims to elucidate the guidance of constructivist learning theory to autonomous learning theory to cultivate learners' autonomy and how instructors assess autonomous learners who play an active role in a non-traditional way, explaining the implications of constructivism for autonomous learning.
\end{abstract}

Keywords: Constructivism, autonomous learning, scaffolding, assessment, motivation, feedback.

\footnotetext{
${ }^{1}$ Istanbul Aydin University, Institute of Social Sciences, ramash7711@gmail.com

${ }^{2}$ Assist. Prof. Dr., Istanbul Aydin University, Faculty of Education, akbaralishah@aydin.edu.tr

Doi num: 10.17932/IAU.EFD.2015.013/efd_v06i1005
} 


\section{Sosyal Yapılandırmacı Hareket Yoluyla Özerk Öğrenmenin Gelişim}

Öz

Eğitimin amaçlarından biri öğrencilerin kendi kendilerini öğrenme becerilerini geliştirmektir. Eğitim öğrenci başarısını, etkin bir şekilde sürdürmek için sürekli gelişime ihtiyaç vardır. Öğretmenlerin eğitimi daha verimli bir şekilde gerçekleştirebilmeleri için yaratıcı olmaları gerekmektedir. Öğretmenler, öğrencinin katılımı konusunda, değerlendirmesini ve motivasyonunu artırmanın yollarını bulmalıdır. Eğitmenler, öğrencilerin okulda ve hayatta kendi öğrenimleri için güvenilir olmalarına yardımcı olabilir. Yapısal hareket, öğrencilerin motivasyonunu, özerkliğini, kavrayışını, iş birliğini ve öğrenci performansını arttırmak için bağlam ve toplum gibi aktif öğrenmeleri konusunda iddiayı geliştirir. Aslında, bağımsız öğrenme popüler bir hedeftir. Pratik, eğitimsel ve felsefi amaçlar için en önemli olanlardan biridir. Öğretmenler öğrenci yönünü geliştirmek için iskele kullanırlar. Bu makale, öğrencilerin özerkliğini geliştirmek için yapısal öğrenme teorisinin otonom öğrenme teorisine rehberliğini ve eğitmenlerin otonom öğrenme için yapısalcılığın etkilerini açıklayarak, geleneksel olmayan bir şekilde aktif rol oynayan özerk öğrencileri nasıl değerlendirdiklerini açıklamayı amaçlamaktadır.

Anahtar Kelimeler: Yapısalcılık, Kendi Kendine Öğrenme, İskele, Değerlendirme, Motivasyon, Tepkiler.

\section{Introduction}

Seniority of the $21^{\text {st }}$ century is authentic learning; that is, learning that contains the efficiency to think and to stratify scientific knowledge for individual and social goals, as contrasted with solely memorizing and recalling facts. We live in what is familiar as a "knowledge society" in which input can be gained with the click of a mouse. As a consequence, more and more actions require advanced skills that ask people to be capable of reasoning, learning, thinking masterly, making decisions, drawing conclusions, testing theories, and solving problems. Learner autonomy is mostly realized as learners' competence to take great responsibility over their own learning (Dwyer, 2018) and is seen as a significant purpose in education. Effective autonomous learning for most students demands 
important investment to evolve the ability needed to determine learning needs, foster a learning plan, monitor progress, and reflect on results, amongst many other skills. Enhanced autonomy has the possibility to promote students to become more energetic in the process of learning, to get ready them for lifelong learning, and to help them better conduct their own learning outside the classroom (Benson, 2013).

A substantial limitation of teaching is that instructors cannot straightforwardly shift information to learners. Nevertheless, learners want to vigorously institute skills in their intellects. Therefore, autonomous learning means a result of constructivist movement which has explicit enforcement to education. This constructivist movement thinks that learning is influenced by the context and it believes that humans construct their understanding and knowledge from their experiences. So autonomous learners will be continuously trying to make or construct their own knowledge of the actual universe from their understanding of that universe. The founders of constructivist learning theory are Buddha and Lao Tzu and this movement has a long history in the Eastern and Western thought and also it has universal origins in the trace of Bruner (1961), Vygotsky (1962), Dewey (1929), and Piaget (1980). Additionally, the big change from traditional to constructivist approaches in science education context has transformed this area of research on instructors' thought of teaching and learning into a precious way that may shed light on their educational practices (Alt, 2018). The modern program involves the educational program to schooling technology teaching and science by conveying the concentration from conventional approaches to student-directed ways. Furthermore, other terms are employed to explain the impression of the development of education and to support learning autonomy such as scaffolding, assessment, motivation, and feedback. Learners with more positive intellectual brains relish better scholarly achievement (Farruggia et al., 2018).

Autonomous learners, in the constructivist classroom, construct their grasping and knowledge relies on experiencing things and pointedly contemplating about those things. Importantly, the coming of the new technologies in schools has inserted new styles into the pedagogic language 
which are developing scientific thinking and increasing peer discussions to foster autonomous learning. It looks for engaging learners with technical and empirical actions via the achievement of advanced educational ways that describe the instruction of skill and advances in computer technology for the $21^{\text {st }}$ century and this happens especially in flipped classroom "We used the 7E model - Elicit, Engage, Explore, Explain, Elaborate, Evaluate, Extend - to create this lesson in order to promote constructivist learning" (Gunning et al., 2018).

Constructivist movement is a theory of education established in psychology which shows how mankind constructs their sense. This study, accordingly, argues constructivism learning theory which has a significant role for autonomous learning and it explains how the autonomous learner is a result of this constructivist learning theory. To what extent does constructivism impact the developing of learner autonomy in education today and how teachers assess autonomous learners in the classroom or can autonomous learners be assessed? The objective of this article is to elucidate the guidance of constructivist study theory to autonomous learning theory to cultivate learners' autonomy and how instructors assess autonomous learners in their lessons that play an active role in a non-traditional way, clarifying the implications of constructivism for autonomous learning.

\section{The relationship between constructivism learning theory and learner autonomy}

As a basic academic direction, social constructivism has supplied suitable theoretical support for teaching practice and it gained much awareness. Its essential connotation is that knowledge is from social construction. Meaning is not an objective presence separate of subject human being but a strong construction in human action of learning the outer world. The enlightenment of social constructivism on autonomous learning is profound since it seeks to modify our understanding of the nature of awareness. Learning inevitably occurs in a certain particular climate and is attained through interaction with others. So, the environment contains not only classroom environment but also education, social culture, interpersonal relationship, and family. Undoubtedly, we should pay attention to teaching learners. Teachers should adjust their roles from traditional classroom to 
constructivist classroom where students should be supplied with learning experience chances to inspire the learning climate in the advantage of constructing personal sense so that learners can evolve their autonomy and develop their capability of stratifying learning organization with the goal of active learning. Such learning is more effective.

Consequently, constructivism learning theory focuses that "learning" is the core and learner autonomy should be granted full function and it contracts that learners are strong constructors of knowledge, learning subjects, and meaning (Anagün, 2018). Therefore, the duty of the instructor in the social constructivism essentially symbolize the role of guider, assistor, and organizer and learners should not only grasp new knowledge but also criticize and analyze new information during the process of the learning. Teachers' previous task is to encourage motivation of learner and will then connect link content with knowledge and experience of the learners fundamentally. Thus, the cultivation of autonomous learning completely relies on the constructivist learning theory.

Interestingly, autonomous learners will receive the input through meaningful explanation under particular socio-cultural background. However, multimedia technology will take an important role in the enlightenment of learners' capacity for autonomous learning. Multimedia Technology will not only supply learners with ample learning resources but also free students' stress in order to make students detect and construct facts vigorously in education (Polin, 2018; Lin \& Hwang, 2018). In social constructivist movement, autonomous learning is basically constructivist and gets the learners to reflect creatively, critically, assess, experiment, detect, question, analyze, solve, and present what they have learned in different techniques. This theory promotes the evolvement of critical thinking, reflecting, incorporating personal understanding, using authentic materials, and divergent strategies. It lays learning into the detection model and thereby puts a lot of observation of learning into the learners' responsibility and its environment participates the autonomous learners' curiosity and motivates them to learn target objectives. Thus, under the constructivist movement direction, language teaching should grow the ability of learners' autonomous learning in order to make language study have personal meaning for language students and lift their development. 


\section{Teachers and learners Role on 21st Century Skills and Designing Constructivist Learning atmosphere}

There has been a modern affirmation on enhancing the quality of education over the past decade. In this drift, a strong discussion is occurring about the most significant knowledge and skills of the $21^{\text {st }}$ century. Universal education fix movements aim is supplying students to solve sophisticated problems connected with living in a technology-intensive world. Recently, autonomous learners are digital students and independent thinkers. They are engaging in the world by digital computing devices including the games, iPads, cellular phones, and computers. Conversation, context, meaning construction, and collaboration are the four main attributes of a learning environment as shown in Figure 1 and cited in (Guo. 35).

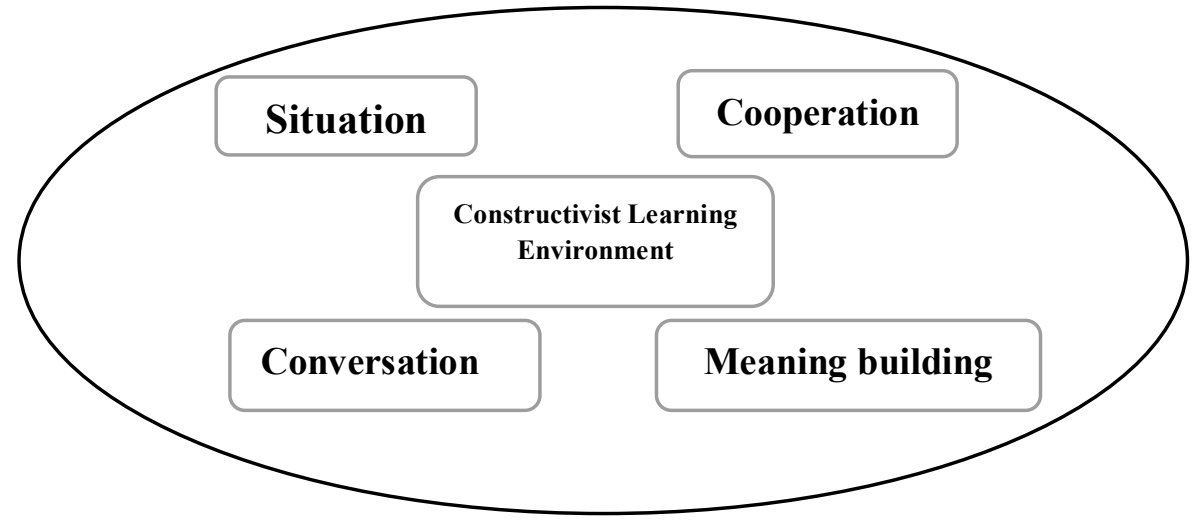

Figure 1: Constructivist learning situation of the four major attributes

It is clear that the purposes of education can no longer straightforwardly supply essential literacy proficiencies for the learners and systems of education should supply higher class thinking skills for all learners. Wherefore, education systems should unify " $21^{\text {st }}$ century skills" into the substance curriculum so as to enable learners to improve the skills, knowledge, and characteristics that will drive them to become actively autonomous learners. Constructivist movement is a vision of learning that learners effectively build knowledge and learn relied on their engagement with their environments. In this movement, learning is happening not 
because of the conversion of knowledge from teacher to learners via text, but because the learners explain and grasp their surroundings. For teachers, to use any new creative teaching approach demands a level of personal willingness to take adventures. Constructivist classroom demands a significant shift in motivation towards the foster of open-ended discovery. Thus, the function of the instructor is to simplify activities that will instruct the learner into enhancing meaningful notions (Anagün, 2018; Honkimäki and Tynjälä, 2018). It is important to help learners make connections of real-life and this starts with students' monitoring, allowing them to stratify their knowledge to be autonomous and expert learners. Knowledge, awareness, and experience of autonomous learners support them to engage in the classroom. This interaction instigated a lot of enthusiasm for students.

Constructivists must regulate a study atmosphere to promote education about the pedagogical impulsion of constructivism. Constructivist movement focuses collaborative forms of instruction and self-discipline, actual learning environments and personally oriented inquiry programs. It is significant since nowadays there is a lack to evolve instruction and learners learning lead to the several distinctions learners bring with them to the teaching-learning process and the several elements that have a significant impact upon the programs students make sense of the prepared input, way the learning process, apply autonomy in learning, and explain their skills and obtained information. Therefore, training needs to be reacting quickly and positively to these distinctions so that learners can gain suitable guidance, meaningful learning experiences, and support for learners to become effective and enhance their autonomy in their lifelong learning.

Palmaru (2016) argues that Schmidt presented into constructivist discourses his perspective that there is no community without culture and no culture without community, focusing on the relationship between communication, culture and community. Fortunately, it has been approved that interactive learning has a predominant position in an institution by sharing significant and vital information, wisdom, data, and knowledge to meet the purpose learning needs and to build interpersonal relationships. 
Through communication, autonomous learners share their care and vision; promote and aid growth; build trust; and so much more in the panoply of human relationships and experience. In addition, Vygotsky's work is one of the foundations of constructivist movement which focuses on the social interaction and the well-known notion of the zone of proximal development and for him ZPD happens in this zone. The ZPD is the range between learners' power to achieve a task under instructor guidance and peer subscription and students' ability solving the problem autonomously. Vygotsky's theory supports learning contexts in which learners function a significant role in the learning process. Both learners and teachers are therefore transferred, as instructors should collaborate with their learners so as to help facilitate meaning construction in learners. Therefore, learning turns out a reciprocal experience for both the instructors and learners.

Vygotsky's theory states that knowledge is co-constructed and there are other idioms which are used in relation to this theory such as scaffolding by which learners may gain confidence and autonomy (Reinders, 2018; Colter and Ulatowski, 2017).

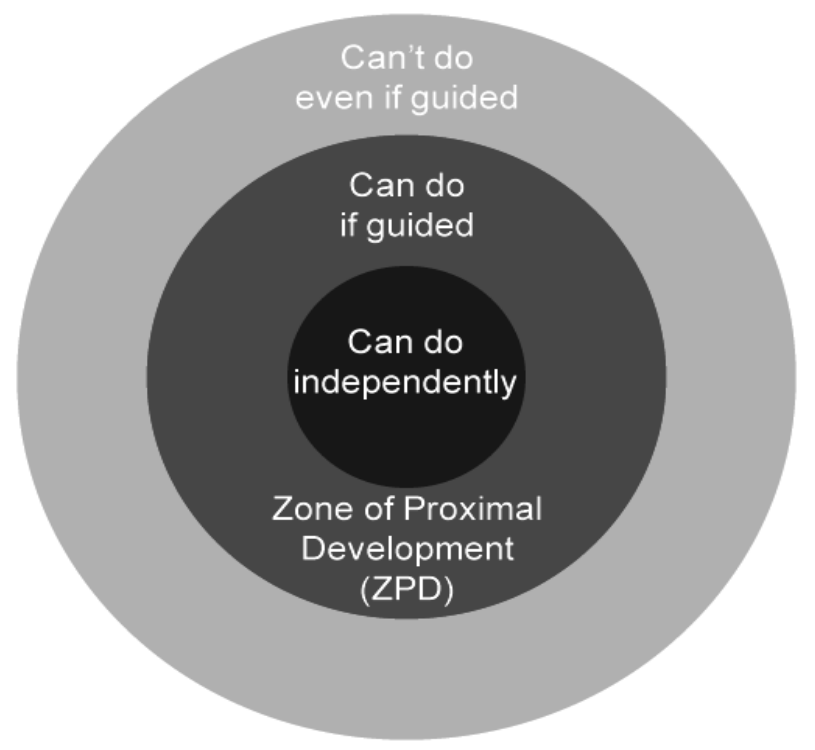

Figure 2: Zone of proximal development (ZPD) 
Recently, feedback and motivation occupy an ultimate goal to evolve students' performance to show autonomy and self-direction (Gan, Nang, and $\mathrm{Mu}, 2018$; Laughlin and Alami, 2018). It is supposed that when feedback to learners is supplied conveniently and aimed at the suitable level, use of feedback information can help to reduce the cavity between learners' current level and desired achievement. Therefore, it has been approved that optimal feedback on learner achievement is as a central advantage of prosperous instruction for instructors of all subjects and grade standards and feedback can be a tremendous motivator mostly when it is in restraint to goal-driven efforts.

Those learners can make connections between different contexts, gaining knowledge which supports them to see deep structures. As teachers, we do not use feedback just to assess learners but feedback helps autonomous learners to conceive what they can do to enhance deepen grasp and experiences. The effective feedback comes when instructors use guiding rubrics with specific criteria or benchmark detailing expected findings from a specific lesson or task and allow learners, instructors, and sometimes fellows to check and debate progress and the final outcome. It is, however, the feedback that is likely to have the greatest influence on autonomous learning. Teachers make feedback a useful and practical practice and they work with learners to design a new project. They get learners to propose elements, interconnections or targets and record their responses in a mindmap. By using feedback, teachers can give a particular number of points for every technically correct answer, with extra points for more imaginative and actionable offers. At the end, brainstorm about ways to fine tune and even implement the plan they up with. Thus, the role of the instructors is to support autonomous learner by stimulating learners to control over their own learning, guiding them to experience a sense of will to define their personal behavior.

\section{How teachers assess learner autonomy in a constructivist mode}

According to the social constructionist view, education is a creative, if sophisticated attempt. Instructors are tasked with linking school program and learners' life by means of enhancing reliable contexts for students to participate with strict connotations and instruments, by means of supplying 
responsive help as learners tackle challenging actions, making use of learners' achievement and performance for assessment and upholding dialogue as well as collaboration. It is vitally important to consider that schools ask instructors to make modification on assessment and materials program (Ortega, Cabrera, and Benalcázar, 2018). Assessment demands learners to be autonomous learners actively involving in and enhancing ownership of their own learning by means like setting personal learning targets, conducting self-assessment monitoring learning progress. Learners carrying out assessment ought to observe their own learning progress, which requires a high degree of learner autonomy and functional engagement. Autonomous learners observe their learning progress regularly by keeping a record of their learning; checking previous learning with respect to learning aims set, and making real decisions about future learning (NG, 2018).

Self-assessment, which is as an advanced tool for teaching, promotes instruction by activating discussion through which instructors can determine fissures and students' learning needs. According to teachers in the constructivist classroom, self-assessment is the wave of the future because it creates real autonomous learners and they want to throw out everything traditional. We cannot consider teachers' role in the constructivist classroom as facilitators only; teachers conduct their classroom in ways make learners take control over their own learning process. In whatever way, we do not feel that the traditional role of teachers is outdated since information is so unhesitatingly available. Therefore, it is necessary for teachers to become of an expert instructor who models the material and then asks learners to try out the behavior, encourages them to set a target for using it, and then promotes them to assess how well they are doing their tasks.

The first move towards the realization of self-assessment is lifting awareness of the value of this formative process; both teachers and learners need to grasp the significance of checking one's work to diagnose progress. Another case is access to assessment criteria. Students should have an obvious understanding of the standards that decide their achievement. Otherwise, they may have challenges determining fissures in their abilities. It develops learners' metacognition and enhances their learning autonomy. So, assessing autonomy may be basic for its evolvement in institutional 
contexts and absolutely helps learners to take ownership of their own learning. (Kadri, 2018; Baker et al., 2017; Borg, and Edmett, 2018).

\section{The implications of constructivism for autonomous learning}

Central to the belief of constructivism is that training is a vigorous operation. Constructivism demands an instructor to conduct as a guide whose major duty is to support students become strong contributors in their education. Besides, to make relevant attachment between pre-existing information and the approaches underlined in study. Relied on the analysis above, we have consciousness that constructivist movement puts forward new demonstrations for learning because it is ultimately learning theory. Therefore, social constructivism has significant meanings for learning to evolve autonomous learners' comprehensive trait.

- Confirm communication and cooperation and train learners' mutual consciousness because in traditional classroom cooperation is abandonment.

- Learners' prior knowledge, thinking mode, experience is the kickoff of teaching.

- Learners have more opportunities, more respect, and more trust, constructing harmonious relations in their lifelong learning.

- Originate a better teaching atmosphere.

- Autonomy relies on learners' willingness to take liability, underlying self-confidence and motivation and it demands awareness of the process of learning.

- The teacher can help autonomous learners to use self-assessment.

To sum up, the fundamental duty of the teacher autonomy is to differentiate a cooperating process that autonomous learners are permitted to build their awareness, and the teacher acts as an instructor, simplifier, and supporter.

\section{Conclusion}

Constructivist movement is a notion that emphasizes that education is an action that is private to the student. This notion supposed that persons attempt to make perception of all the information that they comprehend, and that each person will, consequently, build their sense from that understanding. 
Social constructivist movement exemplified one of the greater motifs in learning. This article debates that autonomy plays a dominant role in the learning process, where learners are anticipated to take some charge for their own progress. The substantial feature of the constructivist learning theory is that it emphasizes the process of student-centered learning. Learners are the focus of teaching activity, and instructors need to play the function of the facilitator, organizer, mentor, and helper, only to promote students in the process of learning activities and learners play the guiding role in the constructivist classroom. At the same time, under the promotion of social constructivism, the essential responsibility of instructors is to encourage self-directed learning of learners to enhance their autonomy. Teachers assist learners to perform self-directed learning, consider learners as the ruler of the learning process, and cultivate learners' learning autonomy. However, need to present chances for learners to reflect on their learning is vivid, and this can be inserted into daily study.

In this article, we have argued that assessment authorizes students to be able to take responsibility for their learning. If students become used to such conversation in the early steps of learning, they may ultimately be able to reflect without instructor facilitation, possibly at first with the assistance of scaffolding. This contains learners not only being sentient of themselves as students with specific targets and motivations, but also being interested and able to seriously reflect on their learning, underlying their aims and motivations, and to evolve it. Moreover, with constructivist movement, learners' learning motivation and feedback can be fully prompted. It can arouse learners' attention in learning and autonomous learning consciousness. As teachers' autonomy, we need to look at the autonomous learners within the conditions of an inclusive classroom that does not just emphasize autonomy and flexibility but also makes the students conscious of how to best command the pedagogical choices the classroom grants.

Overall, the constructivist movement plays an active role in self-directed learning and it is quite relevant in autonomous learning. It also has a profound impact in the future evolvement and promotion of autonomous learners both at home and out of the home. 


\section{REFERENCES}

Alt, D., (2018). Science teachers' conceptions of teaching and learning, ICT efficacy, ICT professional development and ICT practices enacted in their classrooms. Teaching and Teacher Education: Elsevier.

Anagün, S., Ş., (2018). Teachers' Perceptions about the Relationship between 21 st

Century Skills and Managing Constructivist Learning Environments. International Journal of Instruction. 11, No.4, pp. 825-840.

Bakera, A., R., Chenb,j., Linb, T., J., Paulb, N., Andersonc, R., C., and Jahielc, K., N., (2017). Effects of teacher framing on student engagement during collaborative reasoning discussions. Contemporary Educational Psychology: ELSEVIER.

Beckers, J., Dolmans D. H.J.M., Knapen, M. M.H. and Merriënboer, J. J.G. V., (2018). Walking the tightrope with an e-portfolio: imbalance between support and autonomy hampers self-directed learning. Journal of Vocational Education \& Training, DOI: 10.1080/13636820.2018.1481448.

Benson, P. (2013). Teaching and Researching: Autonomy in Language Learning. Applied Linguistics in Action Series. New York: Routledge.

Borg, S., and Edmett, A., (2018). Developing a self-assessment tool for English language teachers. Language Teaching Research, DOI: $10.1177 / 1362168817752543$.

Bruner, J. S. (1961). The act of discovery. Harvard Educational Review, 31(1), 21-32.

Colter, R., Ulatowski, j., (2017). The unexamined student is not worth teaching: preparation, the zone of proximal development, and the Socratic Model of Scaffolded Learning, Educational Philosophy and Theory, 49:14, 1367-1380, DOI: 10.1080/00131857.2017.1282340.

Dewey, J. (1929). The quest for certainty. New York: Minton. 
Dwyer, A., O., (2018). An insight into how a constructivist professional development program can influence practice in six high school chemistry classrooms. Journal of Science Teacher Education, 29:5, 353-377, DOI: 10.1080/1046560X.2018.1457348.

Farruggia, S., P., Han, C., w., Watson, L., Moss, T., P., and Bottoms, B., L., (2018).

Noncognitive factors and college student success. Journal of College Student Retention: Research, Theory \& Practice, 20(3) 308-327. DOI: $10.1177 / 1521025116666539$.

Gan, Z., Nang, H., and Mu, K., (2018). Trainee teachers' experiences of classroom feedback practices and their motivation to learn, Journal of Education for Teaching, DOI: 10.1080/02607476.2018.1450956.

Gunning, A., M., Marrero, M., E., Buonamano, C., and Somers, V., (2018). Waves sound great! first graders explore what makes sound through a 7 E learning cycle. Science and Children.

Guo, H., (2018). Application of a Computer-assisted instruction system based on constructivism. https://doi.org/10.3991/ijet.v13i04.8468

Honkimäki, S., and Tynjälä, P., (2018): Prerequisites for the successful group mentoring of first-year university students: a case study, Mentoring \& Tutoring: Partnership in Learning, DOI: 10.1080/13611267.2018.1471338.

Kadri, N., (2018). Student self-assessment vs teacher assessment: The issue of accuracy in EFL classrooms. In. Mackay, j., Birello, M., and Daniel Xerri (Eds.), ELT Research in Action: Bridging the Gap between Research and Classroom Practice (pp.93-98). UK: IATEFL.

Laughlin, D., and Alami, A., (2018). How to help them 'figure it out on their own', A Journal for Physical and Sport Educators. Strategies, 31:2, 51-53, DOI: 10.1080/08924562.2018.1418572.

Lin, C.-J., \& Hwang, G.-J. (2018). A Learning Analytics Approach to Investigating Factors Affecting EFL Students' Oral Performance in a Flipped Classroom. Educational Technology \& Society, 21 (2), 205-219. 
NG, C., W., (2018). Assessment for/as learning in Hong Kong English language classrooms: A Review. International Journal of Research in English Education. Hong Kong: Research Gate.

REINDERS, H., (2018). Technology and autonomy. The TESOL Encyclopedia of English Language Teaching, John Wiley \& Sons, Inc. DOI: 10.1002/9781118784235. eelt0433.

Ortega, D., P., Cabrera, J., M., and Benalcázar, J., V., (2018). Differentiating instruction in the language learning classroom: theoretical considerations and practical applications. Journal of Language Teaching and Research, Vol. 9, No. 6, pp. 1220-1228, DOI: http:// dx.doi.org/10.17507/j1tr.0906.11.

Palmaru, R., (2016). Constructivism as a key towards further understanding of communication, culture and society. Philosophical Concepts in Radical Const ructivism, Constructivist Foundations, VOL. 12,N1.

Piaget, J. (1980). The psychogenesis of knowledge and its epistemological significance. In M. Piatelli-Palmarini (Ed.), Language and learning (pp. 23-34). Cambridge, MA: Harvard University Press.

Polin, L., G., (2018). A constructivist perspective on games in education. Constructivist Education in an Age of Accountability, doi. org/10.1007/978-3-319-66050-9_9.

Vygotsky, L. S. (1962). Thought and language. Cambridge, MA: MIT Press.

Weinstein, S., and Preiss, D., (2017). Scaffolding to promote critical thinking and learner autonomy among pre-service education students. Journal of Education and Training, Doi: 10.5296/jet.v4i.9871.

Zainuddin, Z., (2018). Students' learning performance and perceived motivation in gamified flipped-class instruction. Computers \& Education, 126 (2018) 75-88 Doi.org/10.1016/j. compedu.2018.07.003. 